\title{
2 \\ Intermediaries and the archive of exploration
}

\author{
Felix Driver
}

\section{The work of exploration}

In 1861, the Schlagintweit brothers published the first of a multi-volume account of their large-scale scientific explorations in India between 1854 and 1858. ${ }^{1}$ Dedicated to the Royal Society, the book was co-published in London (by Trübner) and Leipzig (by Brockhaus), an arrangement reflecting the transnational nature of their expedition, which had been sponsored jointly by the East India Company and the King of Prussia. The bulk of the first volume was devoted to reported calculations of latitude and longitude, together with tables of magnetic observations. This was prefaced by, amongst other things, a narrative of the violent death of the youngest brother Adolph (who was beheaded in Kashgar) and an account of the expedition's 'establishment', or staff.

Unusually, the three surviving Schlagintweit brothers took the trouble to name all the key members of what they called their 'establishment', made up of numerous observers, interpreters and collectors, in addition to a constantly changing

\footnotetext{
1 Schlagintweit 1861. Subsequent quotes come from this volume (pp. 36-42). Of the projected nine volumes of scientific publications, only four were published. The Schlagintweits' expedition was recently the subject of a major exhibition at the Alpine museum in Munich: see Brescius et al. 2015.
} 
retinue of servants. The 'observers' included a Mr (subsequently Lieutenant) Adams, a soldier in the British army; a Muslim named Abdul, appointed as a draughtsman and assistant surveyor in the Madras presidency; a Brahman doctor, Harkishen, who oversaw the work of the plant collectors and undertook surveying work; a so-called Eurasian, Mr Daniel, from Calcutta; Eleazar and Salmonji, so-called 'black Jews' or Jews of mixed race from Bombay, who acted as guides; Ramchand, a Hindu munshi from Peshawar; and Mohammad Hassan, also from Peshawar, fluent in English, Hindustani and Persian. Then there were the 'interpreters', including Mani Singh, described as a 'member of an influential and wealthy family from Johar' in the Kumaon Himalaya, who had previously served the East India Company in an administrative capacity; two of his cousins, Dolpa and Nain Singh, who could read and write Tibetan and who travelled with the Schlagintweits to Ladakh; Mohammad Amin, from Yarkand, who assisted in their expedition to Turkistan, as did Makshut, a Muslim from Delhi; and Cheji, a Lepcha, who interpreted in Sikkim and Bhutan. The 'collectors' meanwhile included long-serving staff such as Mr Monteiro, an Indo-Portuguese zoologist from the Asiatic Society in Calcutta; Dablong, a Bhutia who had travelled with Joseph Hooker in the Himalayas; and Chagi, a Lepcha; Luri, Joha, Khrishna and Mohon Singh, from the Kumaon Himalaya; and a man named as Sukha, from Gwalior. Finally, concerning the personal servants, the Schlagintweits said it was impossible to do with less than eight or 10 at any time, due to what they described as 'the Indian mode of travelling'. Any substantial expedition needed a large workforce 'such as Kalassis (or Laskars), for tent pitching; Bhistis, for fetching water; Ghasvalas, for cutting grass; Saises, for attending to the horses; Chaprassis (or Piuns), for procuring supplies; Chaukedars, for guarding the camp at night; Dhobis, for washing, etc'. Only one of these ordinary servants was actually named - Dhamji, a Parsi, who was employed from start to finish.

The Schlagintweits' roll-call of the names of these key intermediaries amongst their employees is relatively unusual in the literature of exploration during this period. While nineteenth-century exploration narratives often highlighted the role of individual guides and interpreters in enabling European explorers to negotiate unfamiliar landscapes, these were often presented as exceptional or eccentric characters rather than as an integral part of an expedition workforce. In this context, of course, naming was not necessarily acknowledging anything like indigenous agency: to the contrary, it was intended to make transparent the nature of the instruments on which European scientific explorers relied. ${ }^{2}$ Like experimenters faithfully describing their apparatus at the start of a laboratory report, the Schlagintweits were presenting for inspection the moral, racial and intellectual characteristics of their employees in the field. At one

2 The Schlagintweits' calibration of their 'instruments' was to be much further developed by the British in their training of 'native surveyors' for the Survey of India, including Nain Singh: see Raj 2002. 
point they described their camp as a sort of 'ethnographical museum of living specimens', a turn of phrase that was anything but fanciful. Drawing attention to the diverse ethnic and linguistic composition of their establishment was intended to inspire confidence in the reliability of their evidence, dependent as it was on the exploitation of local knowledge and local labour. Furthermore, as became clear in later publications from their expedition, several members of the 'ethnographical museum' contributed their own bodies to the service of science (together with those of hundreds of others) by having plaster casts taken of their hands, heads and feet. Yet it was in their capacity as instruments that these intermediaries were most valued. Like any equipment, they had to be tested, and any weaknesses examined, before an account was given of the data they had collected. As far as the Schlagintweits' readers were concerned, the critical factor was the degree of trustworthiness of the 'native observer', especially when that observer could converse in languages unknown to the explorer, and might travel where the explorer could not.

What the Schlagintweits' account also makes clear is something so obvious, so banal, that it is easy to pass over: scientific exploration was a job of work, and major expeditions required large labour forces. Their three and a half years' work on the subcontinent was devoted to the measurement and collection of just about everything under the sun: places (in the form of latitudes, longitudes and elevations), landscapes (in the form of Humboldtian views and panoramas), natural materials (in the form of rocks, soils, animals, plants, even water itself, sampled and bottled for chemical analysis), physiognomies (in the form of anthropometry), religious artefacts and manuscripts, and so-called 'technical products' (including specimens of textile and paper design from across South Asia). ${ }^{3}$ All this cost a great deal of money and effort. By enumerating the extent and characteristics of their labour force, the Schlagintweits were also accounting for their own expenditure, as well as calibrating their instruments. In the process they mapped a division of labour that remained invisible in many other expedition accounts.

The Schlagintweits figure only very marginally in British histories of survey and exploration. Perhaps they achieved little in the way of genuine scientific discovery; perhaps, as has recently been suggested, their nationality was a hindrance to a more generous endorsement. Certainly the death of the celebrated geographer Alexander von Humboldt in 1859 removed their most influential patron, and influential voices in the London geographical community 
subsequently moved against them. ${ }^{4}$ A particularly scathing review of their work was published in the Athenaeum in the summer of 1861, singling out the above account of the expedition establishment for stinging criticism: 'there are actually biographical sketches, written in the most matter-of-fact style, of all the observers, interpreters, collectors and servants, filling seven quarto pages'. ${ }^{5}$ These were compared, with a racist colonial sneer, to 'the dirty pieces of paper which on our arrival at the Indian ports natives force into our hands, recommending their services as washermen, valets or something worse'. It is difficult to judge what offended the Athenaeum reviewer the most: the fact that substantial funds had been provided to Germans who could never really know India, their unembarrassed enthusiasm for data accumulation rather than analysis, or their failure to follow colonial convention in the way the labour of non-Europeans was described. By 'giving the poor natives a character when they have none', in the unceremonious words of this reviewer, the Schlagintweits had shown themselves naïve at best, dupes at worst. Of course it is possible to read this today as an imperial, specifically British, voice railing imperiously against the Germans. But the nub of the issue, I think, is not simply national chauvinism; rather, it lies in the Schlagintweits' presentation of the expedition as a collective project of work, deserving recognition as such. Historians who look for evidence of the labour of locals and intermediaries in the history of exploration and natural history - and many now are doing so - will find much evidence of the contributions of individual headmen, guides, collectors or interpreters, but I can think of few exploration narratives that so systematically delineate the skilled labour requirements of an expedition. Read today, admittedly with a healthy dose of anachronism, it is as if a confession was being made: whisper it quietly, but Europeans were not at all the masters of all they surveyed. Most of the surveying here, it turns out, was done by those others in the Schlagintweits' 'ethnographical museum': Muslims, Hindus, Buddhists, Turks, Jews, Parsi, speakers of Hindustani, Bengali, Gujerati, Maharati, Punjabi, Kashmiri, Persian, Tibetan, Turkish and Portuguese.

\section{Hidden histories of exploration}

For historians, understanding exploration as a collective project of work remains a challenge. ${ }^{6}$ Much of the literature on the subject, scholarly as well as popular, remains resolutely fixated on the individual explorer, whether as

\footnotetext{
4 Opinion at the Royal Geographical Society (RGS) was particularly sensitive. The Council declined the offer of a dedication of the third Schlagintweit volume (on trans-Himalayan routes and a geographical glossary): Schlagintweit to Murchison, 9 November 1861, Everest to Norton Shaw, 29 November 1861, RGSIBG archives, Fellows correspondence.

5 Athenaeum, 17 August 1861: 216.

6 For a notable recent response to this challenge, see Thomas 2015.
} 
hero or villain, and rarely do we hear about the work done by others. This state of affairs provided the impetus for an exhibition on 'Hidden histories of exploration', which I curated with Lowri Jones in London in 2009. ${ }^{7}$ Using the collections of the Royal Geographical Society (RGS) as our base of operations, we wanted to carry out an experiment: was it possible to make the labours of those others more visible, using the very materials stored up by the explorers and their supporters in one of the metropoles of empire?

The exhibition explicitly presented exploration as a form of work, largely the work of non-Europeans, on which the Europeans depended for their lives as well as for their reputations. After all, explorers did not usually find their own way into the bush, across savannah, swamp, ice or sea; they were almost always guided, piloted and portered through the landscape. Who was leader and who was led in this context is a matter for debate. This emphasis on exploration as work reflected a wider conception of exploration knowledge as co-produced. Once you looked for it, we argued, there was plenty of evidence of the contribution of indigenous peoples to the making of new knowledge including but not confined to maps and mapping, as in the case of the charts brought back by early nineteenth-century Arctic explorers based in part on Inuit testimony and sometimes their drawings. ${ }^{8}$ This was presented in one section of the exhibition through the language of 'uneasy partnerships', which was a shorthand way of saying that while explorers and locals worked together, they were not always (in fact rarely) after the same thing.

The notion of bringing 'hidden histories' to the surface, of highlighting and celebrating the labours of 'forgotten heroes' in exploration, undoubtedly had, and still has, a popular appeal. In the process of planning the exhibition, however, it soon became evident that a more nuanced approach was necessary. The opposition between 'the explorer' and 'the local', for example, had its own limitations as a way of capturing the dynamics of human relations in the course of an expedition; indeed, it was a polarity which in some respects could be argued to be a product of colonialism itself. Our initial goal of reversing the terms in which the history of exploration is normally understood, and emphasising the dependence of Europeans on local peoples (for food, shelter, protection, company, information, knowledge), was itself flawed, for it quickly became apparent that the people explorers often relied most upon for 'local knowledge' were strictly speaking neither 'local' nor 'indigenous'. And more often than not, these people were also explorers themselves, like the Africans who led Europeans across the continent or the Amerindians who guided successive expeditions through the river systems of Amazonia. It was in this context that

\footnotetext{
7 Driver and Jones 2009. Exhibition images may be viewed at: www.hiddenhistories.rgs.org.

8 On a celebrated lithograph depicting the work two Netsilik Inuit 'hydrographers', see Driver and Jones 2009: 14-15; Craciun 2013: 183-186.
} 
the figure of the intermediary - or the 'go-between' - seemed to offer a fruitful way of investigating the ways in which knowledge of geography, natural history and ethnography actually gets translated in the process of exploration. ${ }^{9}$

Working across the archives of exploration held at the RGS, it was possible to identify several distinct types of intermediary, including guides and pilots, interpreters, merchants and traders, local rulers and other elites (or those with direct access to them), and individuals regarded as possessing, or capable of acquiring, other kinds of specialist knowledge useful to explorers. ${ }^{10}$ What all these different figures had in common, at least in principle, was access to unusual or privileged forms of knowledge and mobility. Drawing up such a typology is only a starting point, of course, and it is clear from this and other work that there is much more work to do on the term 'intermediary'. To take one example, following Tiffany Shellam's painstaking work on the archives of encounter at King George's Sound, ${ }^{11}$ we need to think more carefully about the extent to which intermediary figures were valued by explorers and colonists precisely because they mediated between various different indigenous groups as well as between locals and newcomers.

A further issue posed by the very title of the 2009 Hidden Histories exhibition, with its seductive promise of whole realms of historical experience waiting to be uncovered, concerned the relationship between archival visibility and what counts as authoritative historical knowledge. Implicit in the rhetoric of 'hidden histories', a term remarkably prevalent in contemporary heritage practice in the United Kingdom, was the imperative of what might be called rescue archaeology. This suggests that in order to retrieve experiences which have been undervalued, or simply forgotten, all that is necessary is a certain amount of digging beneath the visible surface. At one level, this analogy is innocuous enough: digging, after all, requires physical effort, often teamwork, and to that extent provides a workable metaphor for a shared scholarly endeavour. But in the context of the archive of exploration, indeed the colonial archive as a whole, such a metaphor is problematic. On the one hand, it risks minimising the difficulties in engaging with metropolitan archives in which, as postcolonial scholars have long argued, evidence is constructed in very particular and partial ways. ${ }^{12}$ In this perspective, there is not so much a hidden layer of meaning waiting to be uncovered through the application of the scholarly equivalent of a trowel than multiple pits and channels to be worked across such materials; indeed, new layers of interpretation and new kinds of evidence (notably oral history

9 On the role of intermediaries in exploration, survey and natural history, see Raj 2006; Schaffer et al. 2009;

Jones 2010; Kennedy 2013; Smith 2013.

10 Jones 2010.

11 Shellam 2009.

12 Pandey 2000. 
or creative practice) may need to be added before they can be made to generate new stories, suggesting a programme of construction as much as archaeology. On the other hand, easy assumptions about the 'hidden' presence of certain kinds of agency tends to distract attention from the ways in which indigenous presence, as well as the labour of intermediaries, could in some circumstances be all too visible in the archive of exploration.

Like any archive, the collections of the RGS - its books, manuscripts, maps, photographs, artefacts and films - structure the evidence they may yield in certain ways, and it is important to be reflective about that. But this archive does not altogether erase the presence or contribution of locals and intermediaries to the work of exploration, as might be assumed: a more plausible interpretation is that it often makes them partially visible. I do not offer this model of "partial visibility' as a universal principle, equally valid in different settings and for different archives. Rather it is intended as a challenge to researchers to consider ways of deciphering even the most unpromising of materials to release the residue of their meaning beyond that which explorers themselves, and more especially the guardians of the received narratives of exploration, have so often ascribed to them. There are many inspirations for this approach, not least in Australia - I am thinking of the anthropological writings of Greg Dening, the historical narratives of Inga Clendinnen, and the visual re-readings of Bronwen Douglas, to name a few of the more prominent examples. ${ }^{13}$ The notion of partial visibility also encourages us to challenge simplistic ways of thinking about colonial texts and colonial image-making, and to consider in particular what happens, or might happen, when such texts and images travel through space and time. In the context of the RGS, for most of its history an institution closely associated with the 'heroic' narrative of exploration, these are important moves to make.

This argument can be briefly illustrated with a single image from the RGS collections (Figure 2.1). Originally captioned 'Capt Noel kinematographing the ascent of Mt Everest from the Chang La', this iconic photograph was reproduced in the official account of the 1922 Everest expedition. ${ }^{14}$ It speaks volumes about the heroisation of British mountaineering as another form of adventurous colonial exploration. Here what is celebrated is not only the attempted ascent by a British expedition, but also the technological achievement represented by the specially adapted Newman Sinclair camera, with its zoom lens, fully operational at 23,000 feet. Look closely, however, and you will see something

13 Dening 1996; Clendinnen 2003; Douglas 2009. For work which teases out aspects of indigenous history from colonial archives of exploration in Australia, see Nugent 2008; Shellam 2009; Davis 2013; Veth et al. 2008. For examples of related cross-cultural archival work in a variety of other contexts, see Burnett 2002; FogelChance 2002; Govor 2010; Mueggler 2011; Newell 2010.

14 Bruce 1923. 
else: a partially visible Sherpa holding up the tripod, one of eight men deputed to carry the equipment all the way up the mountain. The Sherpa is indisputably there, helping to make the image what it is, but strangely enough he is not usually seen: most captions to this much-reproduced photograph have simply ignored his presence entirely. We may also wonder who took the photograph not Noel himself, I think, though he is usually credited with it. And here there is some telling indirect evidence buried within the RGS archives: a catalogue to a 1923 exhibition of Everest photographs taken by British climbers (held at the Alpine Club to raise funds for the next expedition in 1924) in which this photograph was included. ${ }^{15}$ Of the hundreds of exhibits, by Noel and the other British climbers, this was the only one not attributed, an authorial absence that surely speaks volumes. On this occasion, even if Noel set up the shot, it must have been one of the Sherpas who operated the camera.

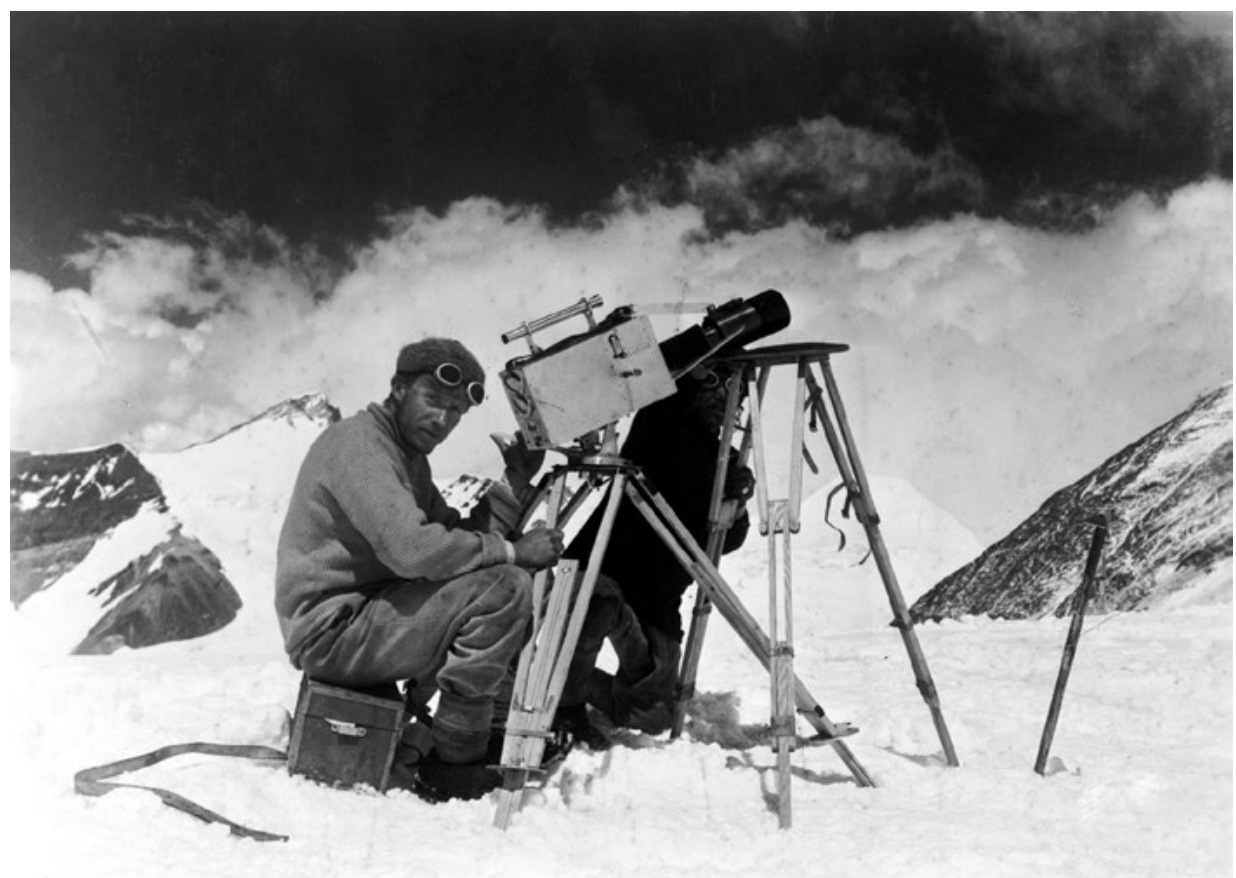

Figure 2.1 'Captain Noel and kinematograph camera with large telephoto lens established on the Chang La [North Col] at 23,000 feet'. Unknown photographer, 1922, 8 × $10 \mathrm{~cm}$.

Source: Photographic print, MEE22/0602, RGS-IBG Collections.

15 Catalogue of the exhibition of photographs and paintings from the Mount Everest expedition, January 21 to February 6, 1923, RGS-IBG Everest Expedition Archives, EE 6/6/3. 
In trawling the archive of exploration for evidence of those who made exploration possible but were rarely out of the shadows - the carriers and guides, the interpreters and fixers - we often find these kinds of traces. In such circumstances, instead of making good an erasure, conjuring into presence the lost stories of those silenced by the archive, we have to deal with conditions of partial visibility: usually fragmentary and often distorted, these are nonetheless signs of another kind of presence. Several issues then arise: under what conditions were these others recognised by contemporaries? When and how, for example, were these individuals actually named? In what ways was their work and its relationship to the project of exploration presented? By what means might we seek to recognise their contributions to the history of exploration and travel today?

\section{Intermediary lives}

In what follows, using selected materials from the RGS collections taken from the period between c. 1850 and 1914, I want to show by example how we might begin to tackle such questions. My first example is the subject of a small pen and ink portrait entitled 'King Freezy' in an album compiled by a naval surgeon named John Linton Palmer (Figure 2.2).${ }^{16}$ The album was compiled in the 1870s, but the portrait was one of several said to be 'sketched in canoes alongside HMS Portland in 1851 when coming alongside Vancouver's Island (Victoria), N. America'.$^{17}$ Each of the images of people and their material culture on this page repays detailed study in its own right: the fishing tools, kayaks, hats and adornments, and women playing a dice game (possibly a unique picture of the game known as smètalé which was first described 40 years later, when it was remembered rather than played, by the anthropologist Franz Boas).${ }^{18}$ On other pages of this album, Linton Palmer carefully arranged further topographic sketches from his sketch books showing sites and settlement and a burial ground. As documents of First Nations material culture and settlement such materials have a value that goes beyond the antiquarian - similar kinds of materials have figured, for example, in multi-million dollar First Nations land claims.

\footnotetext{
16 This section draws on work in progress on the Linton Palmer albums that forms the basis of a forthcoming publication.

17 The page may be viewed in one of the galleries at: www.hiddenhistories.rgs.org.

18 Maranda 1984: 5-48.
} 


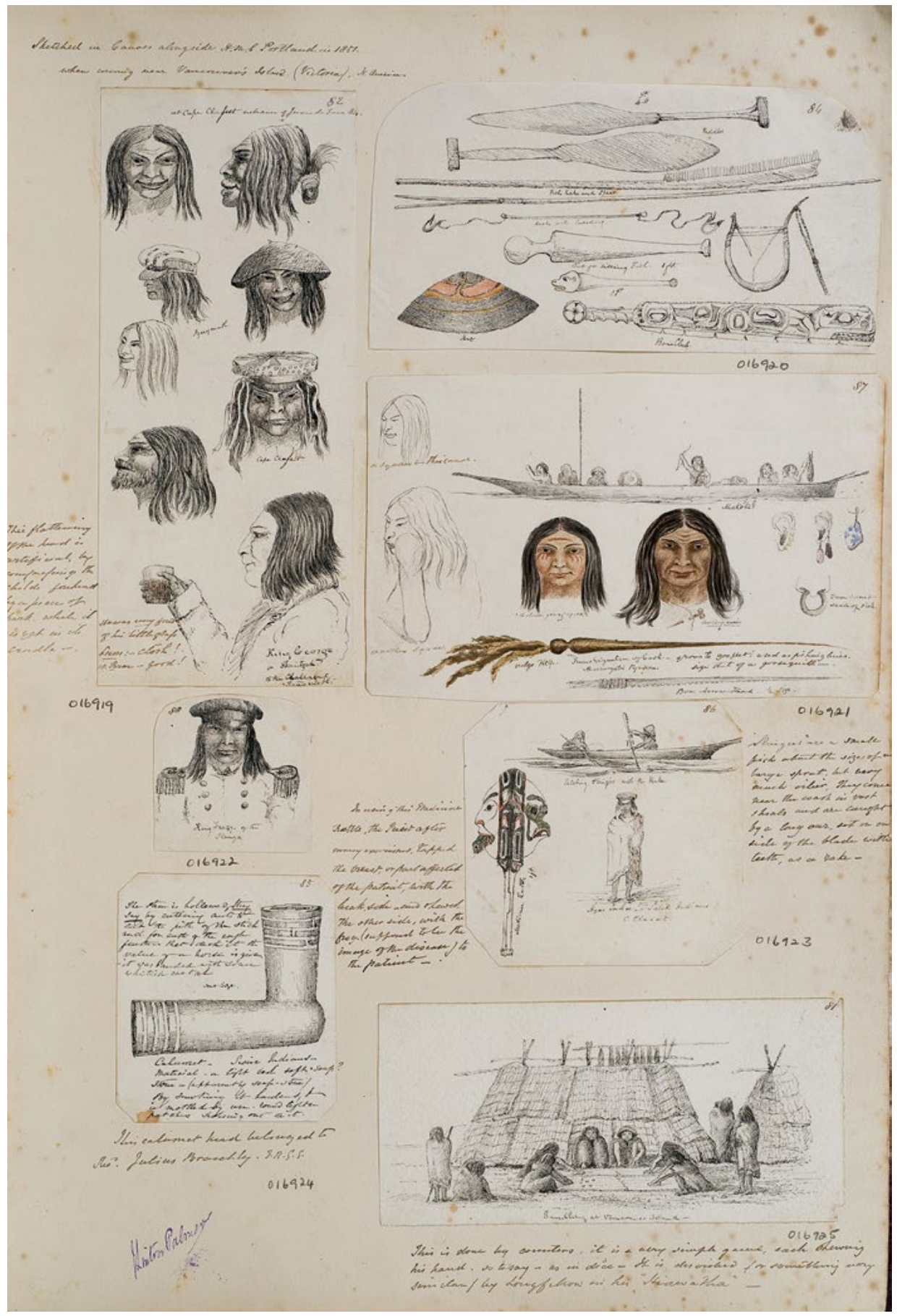

Figure 2.2 'Sketches from Vancouver Island', 1851.

Pencil, pen and ink with watercolour, $52 \times 36 \mathrm{~cm}$.

Source: John Linton Palmer, Album no. 4, 'From Chile to the Arctic', F30/4, RGS-IBG Collections. 
The making of sketches by naval officers was an integral part of the practice of both naval survey and natural history, and had been at least since the days of Cook and Vancouver. ${ }^{19}$ In this context, the sketch 'on the spot' was a memory device, a guardian against fickle memory, designed to record objectively what was seen, often fleetingly. However, in this case the album format presents a further order of memorialisation, re-contextualising the sketch as both a memory object and a form of evidence. In this context, Linton Palmer's albums might be seen as a personal appropriation of the grand atlases of earlier naval expeditions, mapping cultures through their artefacts depicted, as here, as specimens. So a genuinely historical reading of such images requires attention to both the epistemology of the sketch and the cultural meaning of the album. But it also requires something else - an awareness of the circumstances under which the sketches were made, and a knowledge of the key role in these transactions by intermediaries.

Such portraits of people and their material culture required a degree of negotiation and exchange, often in the form of barter. A naval vessel dropping anchor in Esquimalt Bay for little more than a week would allow the officers some opportunity for limited exploration, walking and sketching, a process mediated by interpreters, guides or other local authorities. It is in this context that 'King Freezy' makes his appearance. It is important to make careful note of the date of these sketches - July 1851, just a few years after the establishment of a regular British military presence on the north-west coast, including the construction of a palisaded fort at Victoria. The systematic colonisation of Vancouver Island was yet to come: at this point the island's indigenous population has been estimated as at about 17,000, compared to a few hundred white settlers. The establishment of the fort attracted several groups (including the Songhees, part of the Lekwungen peoples) to move their winter settlements to the north-west shore of the harbour (opposite the fort) in order to trade with the colonists. ${ }^{20}$

In the early 1850s, James Douglas, the chief factor and then governor of Fort Victoria, made the first treaties with the chiefs of a number of local tribes, exchanging blankets for land. ${ }^{21}$ One of these chiefs who signed was King Freezy. Except that he was not called by that name in the treaty. The Songhees people themselves knew him as Cheealthluc. Four years earlier, the travelling artist Paul Kane had painted his portrait in oils, part of a series of portraits made on the model of George Catlin's gallery of North American Indian types. ${ }^{22}$ A later carte de visite photograph (in the Royal BC Museum archives) shows

19 Smith 1985; Martins 1999; Greppi 2005.

20 On developments at Fort Victoria and the subsequent history of settler-indigenous relations in this part of Vancouver Island, see Mackie 1997, chapter 11; Lutz 2008, chapter 4; Edmonds 2010, chapter 4.

21 Duff 1969.

22 Keddie 2003; Lister 2010: 276-277; Pratt 2013. 
him once again in naval uniform, prompting comparison with the army jacket of Aboriginal intermediary Bungaree recently discussed by Grace Karskens in Aboriginal History. ${ }^{23}$ Such portraits of Freezy/Cheealthluc bear further examination precisely for their differences, because they provide hints of a different kind of history of image-making, in which indigenous peoples are not simply the subjects of views, but active in the making of their own images, differently in different contexts - as Freezy in naval uniform, as Cheealthluc in indigenous dress. It seems from the surviving evidence that he acted as the key intermediary figure between the Songhees and a variety of newcomers and visitors, including Linton Palmer.

This example highlights how intermediaries could, under some circumstances, become 'characters' in Western eyes, as they were engaged by successive explorers and travellers seeking access to local cultures. The same could be said of some of those employed on larger-scale exploring expeditions in many other parts of the world. Intermediaries such as Bungaree in Australia, Sidi Mubarak Bombay in East Africa or Pedro Caripoco in Amazonia assisted successive generations of explorers, sometimes becoming minor celebrities in the literature of travel and exploration. ${ }^{24}$ Yet their work was liable to be presented to the readers of travel narratives in terms of fidelity rather than agency - these were often cast as more-or-less faithful followers and loyal servants, not recognised as initiators of exploration. In rare cases, as with the 'pandit' Nain Singh who was awarded the much-coveted RGS Gold medal for his contribution to the mapping of Tibet, Ladakh and Central Asia (much of it covertly undertaken in territory beyond British control), recognition of exceptional labours could be made. And yet this was a particular kind of agency, more akin to the role of the secret agent than the autonomy we usually associate with the term: Nain Singh, whose first experiences of expedition-making were learned with the Schlagintweits, was by the 1860s, quite literally, a subaltern. The story of the 'pandits' secret missions on behalf of the Survey of India - supposed to have been undertaken with the aid of prayer wheels (in which maps were secreted) and rosaries (whose beads were used to count paces) - was soon incorporated within imperial mythology. The literature of the Great Game has framed and limited the ways in which this story has been told: conceiving exploration as espionage may create a new kind of hero, but it does not pose a challenge to colonial ways of thinking about intermediaries as instruments of British power. ${ }^{25}$

In this context, the figure of the 'native' surveyor in British India might usefully be contrasted with that of the interpreter. (Interestingly, some of the pandits themselves employed interpreters on their travels - even the most celebrated

23 Savard 2010: 69-70; Karskens 2011.

24 Driver and Jones 2009.

25 Jones 2010; Raj 2006. 
intermediaries sometimes needed their own intermediaries.) Karma Paul, who worked for the British on successive Everest expeditions between 1922 and 1938, provides a good example of the value placed on the role of the interpreter as a go-between. Born in Tibet and raised by missionaries in Darjeeling, Karma Paul - or Palden as he was born - became a master of many languages. His role as a broker between the British climbers and Tibetan authorities was undoubtedly important, and indeed was recorded for posterity in John Noel's 1922 film, Climbing Mount Everest, the earliest moving images of Tibet which survive. A key scene in the film shows the interpreter Karma Paul acting as a go-between, quite literally, between the monks of Rongbuk monastery and members of the British expedition team, at the foot of Everest. ${ }^{26}$ Noel's intertitles present this moment as a vital rite of passage, with the Head Lama giving his blessing for the planned ascent. At this time, Nepal was closed to the British, and so the Northern route was the only way of reaching the mountain: the agreement of the Tibetan authorities was thus an essential precondition for any future expedition.

But there is more than one way of viewing this scene. On the basis of clues in the footage, including the gift of a bronze statue of a white Tara presented by the Head Lama (which we know was actually presented later) we can surmise that the footage was made after the climbers had returned from the mountain, following a disastrous accident in which eight Sherpas were killed in an avalanche. ${ }^{27}$ Karma Paul's prominence in the scene reflects the importance attached to local negotiations, and yet elsewhere here is evidence that his performances also gave rise to suspicion. General Bruce, leader of the expedition, commented in the official expedition report on the ease with which he moved between British and Tibetan modes of behaviour, treating it not simply as a skilled accomplishment but rather as a source of amusement. Yet Karma Paul used the British climbers as much as they used him: by cornering the market as far as interwar British expeditions were concerned, he secured reliable and well-paid employment, and connections which otherwise would not have been available to him. It took decades of struggle and determination for the Sherpa climbers to achieve the same level of recognition.

The contexts in which exploration took place inevitably shaped the kinds of roles available to intermediaries. In some situations, explorers and travellers developed close personal relationships with intermediaries in the field, even to the extent of describing their role in terms of partnership. One compelling example is that of Juan Tepano, who worked as an assistant for the Quaker ethnologist Katherine Routledge during her archaeological fieldwork on Rapa

26 The footage may be viewed at: hiddenhistories.rgs.org/index.php/gallery.

27 Driver and Jones 2009: 40-41. 
Nui, or Easter Island, in 1914-15. ${ }^{28}$ Tepano was a respected and influential figure on the island who had previously served in the Chilean military. Routledge's reliance on him as her key intermediary is clear from the archives of her fieldwork, which survive at the RGS. He provided access to sites and, crucially, to people with stories to tell about the material culture and history of the island, notably his own mother, Victoria Veriamu, probably the oldest woman living on the island at the time. Routledge placed great value on the methods of what would now be called oral history, as a way of making sense of ethnographic materials gathered by previous travellers. She credited Tepano with primary responsibility for the success of the expedition. Interestingly, 20 years later he played a similar role for the Swiss ethnographer Alfred Metraux. As Jo Anne Van Tilburg has argued, Tepano used his role as intermediary to create a niche for himself as the guardian of the cultural history of the island; indeed, she concludes that 'he single-handedly identified, collected, recorded, influenced, shaped and reconstructed the quintessential data all researchers today regard as the ethnography of Rapa Nui' ${ }^{29}$

Cheealthluc or Freezy, Sidi Mubarak Bombay, Pedro Caripoco, Nain Singh, Karma Paul, Juan Tepano: all intermediaries working in different ways and on very different kinds of expeditions. To their names may be added countless others more familiar in an Australian context, most famously Bungaree, and of course many more unnamed individuals. In most of the cases I have discussed, exploration was closely associated with the extension of colonial and military influence; and in the remainder, the imbalance of power was clearly evident. The role of the intermediary should not be romanticised: go-betweens were vulnerable to criticism for getting too close, or not getting close enough, to those who employed them. The language of partnership in this context is necessarily compromised by the wider inequalities that characterised the colonial era. Yet by working carefully and creatively across the archives of exploration, we can begin to tease out aspects of the history of such relationships which may exceed and even defy colonial definition.

\section{Conclusions}

Recovering the historical agency of intermediaries requires new ways of thinking about exploration, involving a wider variety of actors and relationships than have usually been considered. It also requires sensitivity to the politics of language, especially of names and naming, which is an essential part of the

\footnotetext{
28 Van Tilburg 2003: 182-184.

29 Jo Anne Van Tilburg, 'Easter Island's ethnographic triangle', Easter Island Statue Project, 4 May 2009, www.eisp.org/1853/.
} 
story. In this context, the biographical mode in which much 'recovery' work in heritage and museums is done - which seeks to tell the stories of lives previously hidden from history - is a necessary but hardly sufficient step. Indeed, in the context of exploration, there is a risk that turning the spotlight on the agency of intermediaries such as guides, consultants and interpreters simply replaces one kind of hero myth with another.

In this respect, we must tread a fine line between what might be called salvage biography and critical history. To emphasise the vulnerability of European explorers and their reliance upon local knowledge for their survival in unfamiliar environments is also to rescue local guides, interpreters and other go-betweens from what E.P. Thompson once called the condescension of posterity. ${ }^{30}$ It may also mean celebrating their contributions as explorers in their own right. Publicity for the 2009 'Hidden Histories of Exploration' exhibition thus suggested that the true heroes of exploration had for too long remained in the shadows. This approach was reinforced by the use in exhibition marketing of Thomas Baines' oil painting entitled A Malay native from Batavia at Coepang, produced while he was artist and storekeeper for the North Australian Expedition in 1856. ${ }^{31}$ At an early stage in the planning, the exhibition designer Joe Madeira referred to this painting as the 'hero image', a marketing term which refers to the focal point of a brand design, especially in the web environment. He drew from the image an attractive palette of colours which were then reproduced in banners, posters and other media. In this way the heroic mode of popular histories of exploration was wilfully exploited in order to celebrate an alternative pantheon of heroes.

However, while salvage biography has its uses, it also has some key limitations. These came home to me when I was asked on one occasion just how many 'hidden histories' we had found in the course of our research. The question was entirely reasonable so long as you assumed that discrete and readily identifiable life stories were buried in the archive, just waiting to be unearthed and celebrated. In the subject of exploration, the celebratory model of heritage practice finds a field in which the biographical mode is already dominant, and its search for alternative heroes risks reinforcing its privileging of individual agency. Furthermore, as Lowri Jones has shown in her research on Nain Singh and the Pandits, the figure of the heroic Indigene has a longer history than

30 The phrase comes from the preface to Thompson's The Making of the English Working Class, first published in 1963.

31 Carruthers and Stiebel 2012. Baines' portrait of the unnamed 'Malay native' formed the centrepiece of publicity for the 'Hidden Histories of Exploration' exhibition. Through research on Baines' diaries, he was named as Mohammed Jen Jamain, a local magistrate (Jones 2010; Driver 2013). 
might be imagined. ${ }^{32}$ During the colonial era certain kinds of local agency were not only recognised but celebrated, indeed mythologised. That is one reason we need to be wary of them today.

An alternative approach would highlight the networks, resources and practices on which exploration depended, and through which intermediaries gained their influence. So we need to consider the spatial infrastructure and logistics of expedition-making; the role of in-between places as well as people, the significance of sites of recruitment, supply and pay-off, such as Zanzibar where porters and supplies for the best-known African expeditions were obtained; Kupang where Thomas Baines and many other travellers refitted their vessels and obtained food and animals for their expeditions; Darjeeling where the British recruited their Sherpas; or ports of call on the Rio Negro beyond Manaus. At these various sites were crystallised sets of historical and geographical relationships involving regional and interregional employment practices, trading networks, political histories, family structures, large-scale migrations, and religious change. It is by considering these intermediary sites - the bases from which expeditions were planned - that a richer and more inclusive history of exploration can emerge.

\section{Acknowledgements}

This paper was originally given as a keynote lecture at The Australian National University conference on 'Local Intermediaries in International Exploration', July 2013. I would like to thank the convenors and other participants for their helpful comments. The paper has also benefitted from discussions following public lectures at the Deutscher Alpenverein in Munich and at the Gotha research institute of the University of Erfurt.

\section{References}

Armitage, Geoff 1992, 'The Schlagintweit collections', Earth Sciences History 11: 2-8.

Brescius, Moritz von, Friederike Kaiser and Stephanie Kleidt (eds) 2015, Über den Himalaja: Die Expedition der Brüder Schlagintweit nach Indien und Zentralasien 1854 bis 1858, Böhlau-Verlag, Cologne.

Bruce, Charles 1923, The Assault on Mount Everest, Arnold, London.

32 Jones 2010, chapter 2. 
Burnett, D. Graham 2002, "“It is impossible to make a step without the Indians": nineteenth-century geographical exploration and the Amerindians of British Guiana', Ethnohistory 49(1): 3-40.

Carruthers, Jane and Lindy Stiebel (eds) 2012, Thomas Baines: Exploring Tropical Australia, 1855 to 1857, National Museum of Australia, Canberra.

Clendinnen, Inga 2003, Dancing With Strangers: The True History of the Meeting of the British First Fleet and the Aboriginal Australians, 1788, Text Publishing, Melbourne.

Craciun, Adriana 2013, 'Oceanic voyages, maritime books and eccentric inscriptions', Atlantic Studies 10: 170-196.

Davis, Michael 2013, 'Encountering Aboriginal knowledge: explorer narratives on north-east Queensland, 1770 to 1820', Aboriginal History 37: 29-50.

Dening, Greg 1996, Performances, University of Chicago Press, Chicago.

Douglas, Bronwen 2009, 'Art as ethno-historical text: science, representation and indigenous presence in eighteenth and nineteenth-century oceanic voyage literature', in Double Vision: Art Histories and Colonial Histories in the Pacific, Nicholas Thomas and Dianne Losche (eds), Cambridge University Press, Cambridge, 65-99.

Driver, Felix 2013, 'Hidden histories made visible? Reflections on a geographical exhibition', Transactions, Institute of British Geographers 38: 420-435.

Driver, Felix and Lowri Jones 2009, Hidden Histories of Exploration: Researching Geographical Collections, Royal Holloway, University of London, and Royal Geographical Society (with IBG), London.

Duff, Wilson 1969, 'The Fort Victoria treaties', BC Studies 3: 3-57.

Edmonds, Penelope 2010, Urbanising Frontiers: Indigenous Peoples and Settlers in Nineteenth-Century Pacific Rim Cities, University of British Columbia Press, Vancouver.

Finkelstein, Gabriel 2000, 'Conquerors of the Künlün? The Schlagintweit mission to High Asia, 1854-57', History of Science 38: 179-218.

Fogel-Chance, Nancy 2002, 'Fixing history: a contemporary examination of an Arctic journal from the 1850s', Ethnohistory 49: 789-819.

Govor, Elena 2010, Twelve Days at Nuku Hiva: Russian Encounters and Mutiny in the South Pacific, University of Hawai'i Press, Honolulu. 
INDIGENOUS INTERMEDIARIES

Greppi, Claudio 2005, 'On the spot: traveling artists and the iconographic inventory of the world', in Tropical Visions in an Age of Empire, Felix Driver and Luciana Martins (eds), University of Chicago Press, Chicago, 23-42.

Jones, Lowri M. 2010, 'Local Knowledge and Indigenous Agency in the History of Exploration: Studies from the RGS-IBG Collections', PhD thesis, Royal Holloway, University of London.

Karskens, Grace 2011, 'Red coat, blue jacket, black skin: Aboriginal men and clothing in early New South Wales', Aboriginal History 35: 1-36.

Keddie, Grant 2003, Songhees Pictorial: A History of the Songhees People as Seen by Outsiders, 1790-1912, Royal BC Museum, Victoria.

Kennedy, Dane 2013, The Last Blank Spaces: Exploring Africa and Australia, Harvard University Press, Boston, MA.

Lister, Kenneth 2010, Paul Kane, the Artist: Wilderness to Studio, Royal Ontario Museum, Toronto.

Lutz, John S. 2008, Makúk: A New History of Aboriginal-White Relations, University of British Columbia Press, Vancouver.

Mackie, Richard 1997, Trading Beyond the Mountains: The British Fur Trade on the Pacific 1793-1843, University of British Columbia Press, Vancouver.

Maranda, Lynn 1984, Coast Salish Gambling Games, Canadian Ethnology Service, National Museums of Canada, Ottawa.

Martins, Luciana 1999, 'Mapping tropical waters: British views and visions of Rio de Janeiro', in Mappings, Denis Cosgrove (ed.), Reaktion, London, 148-168.

Mueggler, Erik 2011, The Paper Road: Archive and Experience in the Botanical Exploration of West China and Tibet, University of California Press, Berkeley.

Newell, Jennifer 2010, Trading Nature: Tahitians, Europeans and Ecological Exchange, University of Hawai'i Press, Honolulu.

Nugent, Maria 2008, "To try to form some connections with the natives": encounters between Captain Cook and Indigenous people at Botany Bay in 1770', History Compass 6: 468-487.

Pandey, Gyanendra 2000, 'Voices from the edge: the struggle to write subaltern histories', in Mapping Subaltern Studies and the Postcolonial, Vinayak Chaturvedi (ed.), Verso, London, 281-299. 
Pratt, Stephanie 2013, 'Integrating the "Indian": the Indigenous American collections of George Catlin and Paul Kane', in World Art and the Legacies of Colonial Violence, Daniel Rycroft (ed.), Ashgate, Farnham, UK: 59-82.

Raj, Kapil 2002, 'When human travellers became instruments: the Indo-British exploration of central Asia in the nineteenth century', in Instruments, Travel and Science: Itineraries of Precision from the Seventeenth to the Twentieth Century, Marie-Noelle Bourguet, Christian Licoppe and H. Otto Sibum (eds), Routledge, London, 156-188.

2006, Relocating Modern Science: Circulation and the Construction of Scientific Knowledge in South Asia and Europe, Permanent Black, Delhi.

Savard, Dan 2010, Images from the Likeness House, Royal BC Museum, Victoria.

Schaffer, Simon, Lissa Roberts, Kapil Raj and James Delbourgo (eds) 2009, The Brokered World: Go-Betweens and Global Intelligence, 1770-1820, Science History Publications, Sagamore Beach, MA.

Schlagintweit, Hermann, Adolphe and Robert 1861, Results of a Scientific Mission to India and High Asia, Undertaken Between the Years 1854 and 1858 By Order of the Court of Directors of the Honorable East India Company, Volume 1: Astronomical Determinations of Latitudes and Longitudes and Magnetic Observations ... preceded by General Introductory Remarks, Brockhaus, Leipzig, and Trubner, London.

Shellam, Tiffany 2009, Shaking Hands on the Fringe: Negotiating the Aboriginal World at King George's Sound, University of Western Australia Press, Crawley.

Smith, Bernard 1985, European Vision and the South Pacific, second edition, Yale University Press, New Haven.

Smith, Vanessa 2013, 'Joseph Banks's intermediaries: rethinking global cultural exchange', in Global Intellectual History, Samuel Moyn and Andrew Sartori (eds), Columbia University Press, New York, 81-109.

Thomas, Martin (ed.) 2015, Expedition into Empire: Exploratory Journeys and the Making of the Modern World, Routledge, New York.

Van Tilburg, Jo Anne 2003, Among Stone Giants: The Life of Katherine Routledge and Her Remarkable Expedition to Easter Island, Scribner, New York.

Veth, Peter, Peter Sutton and Margo Neale (eds) 2008, Strangers on the Shore: Early Coastal Contacts in Australia, National Museum of Australia Press, Canberra. 
This text is taken from Indigenous Intermediaries: New Perspectives on Exploration Archives, edited by Shino Konishi, Maria Nugent and Tiffany Shellam, published 2015 by ANU Press, The Australian National University, Canberra, Australia. 